\title{
Utopian Fraud: The Marquis de Rays and
}

\section{La Nouvelle-France}

\author{
BillMetcalf
}

\section{ABSTRACT}

While most attempts at creating utopian societies have ended in failure, few were as fraudulent as La Nouvelle-France on the island of New Ireland (now part of Papua New Guinea).

Its founder, the Marquis de Rays, was a charismatic monomaniac who dreamed of creating a South Pacific utopia. He launched this scheme in 1877 and soon investors poured in money, and would-be utopian settlers joined up. During $1880-81$, several hundred people sailed on inadequate ships to where they expected to find utopia, but instead found a swampy, malarial-infested wasteland, surrounded by cannibalistic neighbours. Some were killed while others died of disease and starvation before the survivors made their ways to Australia, New Zealand, other Pacific islands, or back to Europe.

At a sensational trial in Paris, The Marquis de Rays and several associates were fined and sentenced to prison.

In a French courtroom in I884, Charles Marie Bonaventure du Breil, better known as the Marquis de Rays, a French nobleman, was sentenced to imprisonment for fraud. His crime concerned a utopian scheme undertaken "pour 
Dieu et pour la France" (for God and for France) that had led to exile, destitution, and death for several hundred people who sought to establish La Nouvelle-France in what is now Papua New Guinea.

La Nouvelle-France is arguably the biggest fraudulent utopian scheme ever perpetrated.' Hundreds of investors and peasants lost their money and, in some cases, their lives. The governments of France, Belgium, Spain, and Britain, and several Australian colonies, also became involved. Descendants of these would-be utopians celebrate their bad fortune, which eventually became good fortune, in New Italy Museum, Australia, recording their ancestors' suffering through the Marquis de Rays's fraudulent scheme.

In 1832 , the Marquis de Rays was born into a distinguished, noble family from the Brittany region of western France. Like most members of the French nobility, this family had fallen on hard times during the revolution when their castle, Quimerc'h, had been destroyed by angry peasants, and they had to flee to England to escape execution. They returned to France after the Napoleonic Wars, but their position was by then one of genteel poverty. ${ }^{2}$

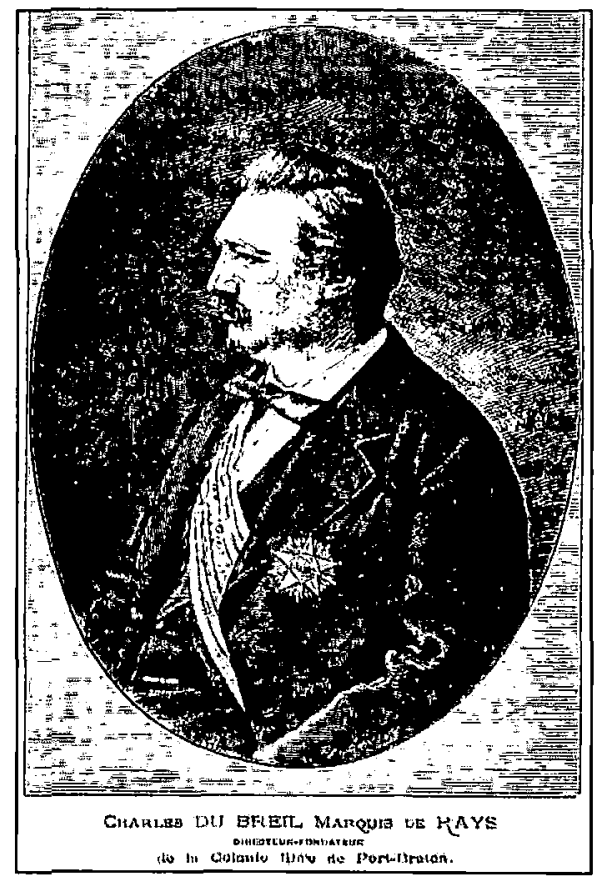

Figure. . The Marquis de Rays: Undated photo but most likely early 1880.

Sourie de Groote 1880, 10. 
A fortune-teller reportedly told the young Marquis de Rays that he was destined for greatness, that he would become a king under whose utopian rule "the disinherited would have the better part and the proud would become humble," and that he would "found a nation where the poor and lonely would live a good life." He dedicated his life to realizing this dream, believing that he had a divinely ordained mission to save the souls of "the black people." As a youth, his friends referred to him as "the little colonist" because of his fantasies about creating a utopian community. When aged twenty, the Marquis de Rays went to America, where he sought the adventurous life of a cowboy on a ranch that he briefly managed, unsuccessfully. He then traveled to Senegal, where he became a trader, mainly in peanuts, again failing, and then tried his luck as a trader in Madagascar and Indo-China, again failing. His record was consistentaiming for greatness but failing in whatever practical pursuits he tried. ${ }^{3}$

In 1880 , Dr. Paul de Groote, a Belgian medical doctor and member of the Scientific Society of Brussels (Société Scientifique de Bruxelles), wrote reverentially about his friend, the Marquis de Rays, in one of the most important primary texts available:" "His exterior, reflecting the sentiment of his power, of his calm courage, and of his exquisite generosity, commands respect and confidence. 'The Marquis de Rays is assuredly born to rule; he has self-assurance, spontaneity, resolution, and a sharp eye; he possesses at the same time a high degree of Christian virtues, military instinct, the genius of the sailor, the foresight of the administrator and the enlightened impartiality of a judge."5 While preparing for his divinely ordained mission, the Marquis de Rays undertook "long and perilous . . . trips, ... visited the most civilized centers of the world; he has penetrated the vast lands of Africa, of America, of Asia and of Australia, always meditating on his mission. In those distant and unexplored regions he has closely studied the morals and conduct of uncivilized, savage tribes, by living amongst them."6

\section{Utopia in the Idyllic South Seas}

In July 1877 , the forty-five-year-old Marquis de Rays revealed to the world his utopian scheme, which he hoped would ensure his greatness and restore him to the noble, divinely ordained position to which he felt entitled. He planned to create a utopian society in the South Seas and advertised for people to join him. ${ }^{7}$ Given the poverty and disruption in France following the disastrous 


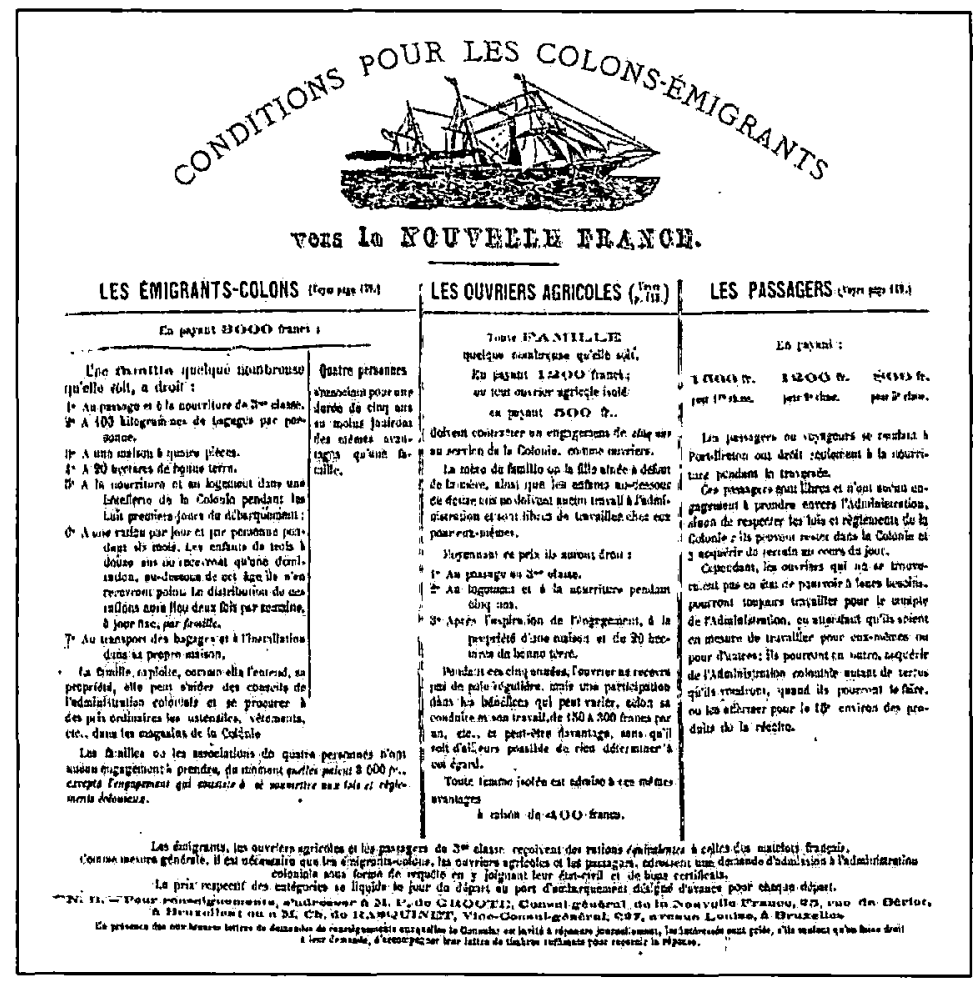

Figure 2. Conditions: This is a copy of the flier that was provided to all investors and participants and which explains the utopia.

Source: de Groote 1880. Annexe VI.

Pranco-Prussian War, many people were interested in escaping-particularly to "utopia." In early I879, the Marquis issued a formal prospectus, seeking colonists for his utopian La Nouvelle-France. ${ }^{8}$

The Marquis de Rays first planned to establish this utopia in the Shark Bay area, near Carnarvon, Western Australia. He argued, erroneously, that "no Government has any claim upon these vast tracts . . no savage people and no settled tribe cultivates the ground-only a few wandering families of timid blacks pass over the limitless waste. The land [therefore] belongs to the first occupier." 9 Based on this assertion, he planned to claim the northern two-thirds of Western Australia, an area about three times the size of France. Not surprisingly, the British government, which held this area as part of its empire, flatly refused. The Marquis bravely vowed to defy the 
British government: "We did think that, under the Australian sun-under the sovereignty of Free England-there was room also for a French undertaking. . . Nevertheless, we intend to carry to these new shores [Western. Australia] the sacred remembrance of our old country. We will give it in perfect freedom the grandest horizon, and its fertile sentiment will alone support our work."10

George Collingridge, an English friend of the Marquis de Rays, recalled, "During the late seventies [1870s], when I was living at Fontenay aux Roses, near Paris, du Breil used to write to me concerning his mad scheme. Our correspondence on the subject lasted a long time, and I received many printed papers, maps, etc., relating to his scheme. He appeared quite astounded when I informed him that the independent French or Breton colony in Western Australia would not be allowed either by the Colonial or by the British Government." Typical of the language of many utopian dreamers, the Marquis de Rays "considered he had a right to start a settlement to be governed by his own rules and regulations" and asserted that "to us, then, belongs the future. On the ocean shore of a new port and a new country we shall establish the perpetuity of our families and hand down our memory to posterity."

Wisely, the Marquis de Rays abandoned foolhardy thoughts of invading Western Australia. Instead, he sought approval from the French government to establish his utopian commune in New Caledonia or New Hebrides but was quickly and firmly refused by French colonial authorities. ${ }^{12}$

Such "trivial" problems of international law did not deter the Marquis de Rays. He next read an account by Louis Duperrey, commander of the exploration ship Coquille, who had visited southern New Ireland for several days in August 1823 and described it as a veritable Garden of Eden. The Marquis de Rays therefore announced that his utopia, "La Nouvelle-France," would be established on New Ireland (now part of Papua New Guinea), which, with great commercial optimism and geographical imprecision, he described as being on the sea route between China and Australia. ${ }^{13}$

\section{The Fantasized Climate and Environment of La Nouvelle-France}

Having never seen or even been anywhere near the selected site, the Marquis de Rays nevertheless proclaimed it to be paradise: "Although under the torrid zone, these lovely islands, caressed day and night by refreshing sea breezes, share the ocean temperature on which they are gracefully sited; 
they relish a perpetual springtime, rarely bothered by hurricanes, volcanoes and earthquakes, everywhere presenting the most enchanting scenery." ${ }^{\prime 4} \mathrm{He}$ described the extraordinarily healthy climate of New Ireland as "excellent. Climatological studies of this magnificent oasis proves that epidemics are unknown and impossible there. Someone who would die in our Europe would live a long life under this beneficial climate." And in spite of all that was known about the serious, frequently fatal, health problems faced by Europeans living in the tropics, he claimed that at La Nouvelle-France, "there are never epidemics of fever or other infectious diseases; nor acute respiratory diseases; these infections do not find there conditions needed for their germination or development; never are there abrupt changes in temperature, and the transition of heat from night to day is of less than one degree." ${ }^{25}$ Not only was this a climatic paradise, but each individual could choose the subclimate she or he preferred and grow a wide range of temperate and tropical crops because "climatic zone changes depend on elevation as well as proximity to the ocean. Altitude, just like latitude, follows the same isotherm lines and shows variation of fauna and flora as one climbs higher. At the bottom of the mountain one finds plants that correspond to the climate of the region; as one climbs higher, the vegetation of the plain gives way to vegetation of cooler regions. Therefore, whether one climbs higher or moves towards the pole, one will cross successive vegetation and tree zones." ${ }^{26}$

This veritable Garden of Eden was surely the answer to any European peasant farmer's dreams because "inexhaustibly fertile soil, abundant sunlight and the precious advantage of excellent conditions ... are exceptionally favorable to developing and maintaining flourishing, long-lasting health." ${ }^{17}$ In contrast, a British official who inspected the chosen site described the soil as being "of a sandy, unfertile nature which made agriculture impossible." ${ }^{\text {"18 }}$ Another European with experience in New Ireland colorfully described the site as "the most sodden, dank, squashy and appalling place on the globe."'s Nevertheless, the sycophantic Dr. Paul de Groote's readers were assured that utopia would be realized there through the unbounded abilities and profound wisdom of his leader: "These are the exceptional conditions provided by this privileged land which was chosen by the Marquis de Rays for this free and Christian colony. All these measures taken by the promoter demonstrate a remarkable wisdom; they follow the rules of good hygiene appropriate to these lands as particularly understood by the leader of this enterprise. All the factors and details about this enterprise reflect the initiative of a man of experience; they demonstrate a 
profound knowledge about the resources which are provided by this rich land, and provide a firm conviction about the complete success of this enterprise."20

\section{Land Acquisition}

The island of New Ireland was not under colonial rule, hence there was no central government with which the Marquis de Rays could have negotiated even if he had wished to. ${ }^{21}$ Hugh Romilly, a British colonial official who visited New Ireland in July 1883, reported, "There has been little communication between the inhabitants of New Ireland and white men. They bear the reputation of being treacherous savages, and up to the present time they have fully justified their bad character." ${ }^{22}$ New Ireland's dense population was ruled by numerous local chiefs, some more despotic than others, whose followers were in frequent conflict, and cannibalism was widely practiced. ${ }^{23}$

Never having been anywhere near New Ireland, the Marquis de Rays praised these violent, disputatious, and cannibalistic natives as being "simple children of nature . . looking forward with rapture to the advent of the colonists, and to the prospect of becoming citizens of the Free Colony, and being recognized as Frenchmen, and helping the settlers cultivate the vine, etc., and being admitted into the fold of Christianity." ${ }^{24}$ Given this, the marquis inexplicably decreed that "as a precaution against any eventuality, a small fort or block-house will be built immediately after the island is claimed, and within its walls will be the administrative buildings as well as the homes of employees and future immigrants." ${ }^{25}$

\section{Intended Governance}

The Marquis de Rays drew up an elaborate outline of how utopian La Nouvelle-France would be governed and, not surprisingly, decreed that he should be the "absolute head, the only master, the creator and the supreme judge in Nouvelle-France's government." There would be no need to fear this because he would not be "arbitrary, despotic or capricious" because his authority would be "based on the principles of a supreme order," with "rules and regulations ... inspired by Christian sentiments with which the colonists agree." Only to God and the Roman Catholic Church, "this most ancient, respectable, and respected religion," would he "subordinate his deeds and his powers." 26 
Practical administration would be undertaken by "Carthusian and Trappist monks and brothers, who excel in this type of work" and whom the Marquis de Rays would induce to join this venture. ${ }^{27}$ Under them, "the colonial administration will achieve its humanitarian goals." ${ }^{28}$

Government, with the Marquis de Rays at the top and with Christian monks and brothers as administrators, would have an intermediate social stratum composed of elements of the old French nobility. ${ }^{29}$ The Marquis de Rays claimed that this complex, hierarchical social and political system would be legitimized by international support: "The acquisition of Nouveau-France today, and the special and increasing support of Spain for this work, the constant protection of United States, the sympathetic encouragement of the Republic of Liberia, the impartiality of England, and the impartial judgment of other powers whose names it would be premature to announce, makes the time opportune for the creation of a perpetual nobility based on the model of the landed estates of England."30 To reassure would-be colonists that their interests would be ensured by these layers of civil and clerical elites, the marquis promised, "The French civil code, modified along Catholic principles, has been adopted for the colonial administration. The Catholic religion is the state religion. Personal liberty of conscience is assured for all colonists. Political legislation and social order are based on the principles of the Catholic religion. The priests, monks, missionaries, and nuns will be established in the colony, as well as doctors, justices of the peace, judges, etc. The commune shall conduct itself with taxation and management in its best interests. The armed forces will be comprised of policemen, gendarmes and soldiers. Military service is voluntary." ${ }^{31}$

Although there is not a shred of evidence that the Marquis de Rays ever seriously contemplated joining those whom he was inducing to join La Nouvelle-France, these would-be utopians were nevertheless reassured that he "will live in the colony with his family." But, before leaving France, he "will take all steps necessary to ensure the full establishment of the colony." Only when all difficulties had been resolved would he go to La Nouvelle-France to join in "the development and expansion of this grand and beautiful enterprise." 32

\section{Finding Recruits}

Dr. Paul de Groote, working on behalf of the Marquis de Rays, edited their newspaper, La Nouvelle-France. ${ }^{33}$ This widely distributed newspaper was 
"profusely illustrated by old engravings purporting to picture South Seas islands scenery. Prospective investors were showered with pamphlets and prospectuses. For a consideration, they could also procure a portrait of the Marquis (for sixty centimes), a map of Port-Breton (one franc), a map of La Nouvelle-France, either in an 'ordinary' edition (fifty centimes) or in a deluxe edition (one franc) and, finally, (for two francs) the 'March of Port-Breton,' composed by the Liberian consul in Paris, one Dr. Febrer, and dedicated to the founder of the colony." ${ }^{34}$

While the Marquis de Rays was a rabid French nationalist, and while La Nouvelle-France would reflect the glories of the Ancien Régime of prerevolutionary France, its residents need not be French: "The agricultural colony at Port-Breton is a French project; but while French nationals will be the majority, there will also be Belgians, Swiss, Spaniards, Italians and English, etc. There will also be Malays, Indians, Chinese and native workers; all being free men." ${ }^{235}$ Each would-be colonist who could invest r,800 francs (about $£ 76$ or US\$30o) was promised transportation to this South Pacific utopia, plus a ready-built house of four rooms and twenty hectares (fifty acres) of land already cleared and ready for cultivation. From this modest investment they could grow crops such as sugar and coffee for which they were guaranteed "to receive a veritable fortune ... without any risk." ${ }^{36}$ People lacking this modest capital could take part for free as long as they agreed to work for the community for five years, at the end of which time they would receive the same house and land package as had the others. Hard labor would be done by coolies imported from China and Malaya or by natives at the bottom of the social hierarchy. This was to be a utopia only for Europeans, ${ }^{37}$

Fantasies of idealized societies flourishing within the warm, South Pacific waters had, of course, been a potent and recurrent theme within European mythology for several centuries, so this scheme, as bizarre as it now appears, caught popular attention: ${ }^{38}$ "From Francis Bacon on, the Pacific was the home of Utopias, and the dream of an Austral land seduced alike philosphes and hard-headed propagandists for Trade and Empire." The Marquis de Rays was a prime example of "the dreaming founders not of trading colonies but of ideal ... commonwealths, who found in Terra Australis or thereabouts a fitting locale for their wild imaginings." ${ }^{39}$

The Marquis de Rays's dream of creating a South Pacific utopia attracted hundreds of Europeans, a broad range of dreamers, social misfits, speculative capitalists, adventurers, no-hopers, desperate peasants, and genuine utopia 
seekers. For Italian and French peasants this was the chance for which they had dreamed. With no idea that they were following either a charlatan or a mad man (or both), they surrendered all personal possessions and waited to board the ships going to establish La Nouvelle-France, with high hopes of prospering in this elitist and capitalist utopia.

The Marquis de Rays employed Edwige Schenini, from Milan, as one of his recruiting agents. Schenini traveled through the Italian villages north of Venice, particularly around Treviso, a seriously impoverished area that had recently been devastated by wars between Austria and the newly formed Republic of Italy. Making outrageous claims on behalf of the Marquis de Rays, Schenini attracted about 250 desperate Italian peasants and artisans to this implausible utopian venture..$^{40}$

The Marquis de Rays induced members of the Missionaries of the Sacred Heart to join La Nouvelle-France, offering free passage from Europe to the colony plus "free food and lodging in the colony and officer-rank for all missionaries; free lands for all their needs; a temporary chapel in the beginning and a church to be built as soon as possible; land-grants and facilities for schools, supply of transport for the evangelization of the natives in various parts of the island; [and] protection for missionaries as agents of the colony."4t Obviously, this offer was too good for missionaries to pass up.

Meanwhile, the Marquis de Rays proclaimed himself King Charles I and came to believe that God had granted Divine guidance to rule despotically over his imaginary domain of La Nouvelle-France. From within his guise of King Charles I, he instructed his lieutenants how to manage the gullible, unfortunate people who followed his utopian dreams: "I have conferred legitimate authority upon you as, I believe, I, myself, hold it from God. Never allow your authority to be questioned. Even should an execution be necessary to enforce your will, do not hesitate."A2

\section{Establishment of La Nouvelle-France}

Over five hundred would-be colonists, including the above-mentioned peasants from Italy, sailed in four ships, Chandernagore, Genil, India, and Nouvelle Bretagne, between 1879 and 1881 , with the first detachment landing on New Ireland on January $16,1880.43$ Instead of finding ready-built houses and land cleared for cultivation, as promised, they found a swampy wasteland. 
Even though their intention was to live together in a utopian community, a visiting missionary observed how quickly they became "quite dispirited, and appeared to have no bond of union or comradeship amongst them." +4

Without a shred of evidence an Australian newspaper enthusiastically reported that the "Marquis de Rays has organised one of the most complete and promising colonising expeditions yet heard of." The reporter, sitting comfortably in Sydney, enthused that "no expense or energy has been spared by the Marquis to make his enterprise a great success" and claimed that these utopian communards "were received with apparent goodwill and friendliness on the part of the natives . . . and no trouble is anticipated from them." 45

Nothing, however, could be further from the truth! From the arrival of the first settlers, this would-be utopian venture was a tragic, frequently fatal, failure. One observer wittily commented, "The colonists could consider themselves lucky that there was not a reception committee of maddened head-hunters . . . due to the fact that the local head-hunters had more sense than to build in the swamps." ${ }^{46}$ A visiting missionary reported, "Some of those who were sick were lying about in a most filthy condition, and some were half naked. I saw some dreadful sights at this time which will not bear to be reported in print." Surprisingly, this missionary also reported that some of the would-be utopians were Protestant, very odd given the Marquis de Rays's intention of creating a Catholic utopia. ${ }^{47}$

The Italian peasants referred to above had sailed from Barcelona on July 8, I880, on the India, under Captain Jules Prevost. India, of 445 tons when previously known as the Ferret, had been the subject of a famous maritime fraud wherein it had allegedly been lost in a storm at sea, and the insurance was collected, after which it was discovered to have simply been renamed and repainted and become the property of the Marquis de Rays. It was never clear if he was directly involved in this scam, although it seems likely that he was. ${ }^{48}$

For sleeping quarters, India had shelflike beds along both sides and in the center, where men, women, and children slept as best they could, with no privacy. After a very difficult three-month voyage, with several births and deaths, they reached New Ireland on October $14,1880.49$ They anticipated finding a bustling, paradisiacal settlement but instead found themselves in a hostile environment, under threat from the natives whom they were displacing, and without the provisions or housing that had been promised. One survivor recalled being "simply dumped upon this inhospitable and untillable land, with cannibalistic savages in the surrounding woods." 50 
On November 13, 1880, almost a month after the Italian peasants had arrived, Dr. George Brown, a Methodist missionary from nearby Duke of York Island, visited and took a number of photographs of the group, recording their sorry plight. In one photo, about twenty-five of the Italians pose in front of temporary shelters made of branches covered with fabric, probably old sails. The heavily clothed Italians stand in sharp contrast to three naked natives, their inclusion in this photo suggesting that amicable relations had been established with a few locals. ${ }^{\text {st }}$ Dr. Brown recorded that day:

The colonists, I found, had erected a large block house and several other buildings, but little or nothing had been done in the way of cultivation or of making provision for the supply of their wants. There were abundant evidences in the settlement of the great preparations which had been made in France for the success of the expedition. A large steam boiler and fireplace were on the beach, together with a great quantity of bricks ... to be used in the foundations of the cathedral which they purposed building. They had also the machinery for sugar refining, a steam crane, incubators, a sawmill, and agricultural

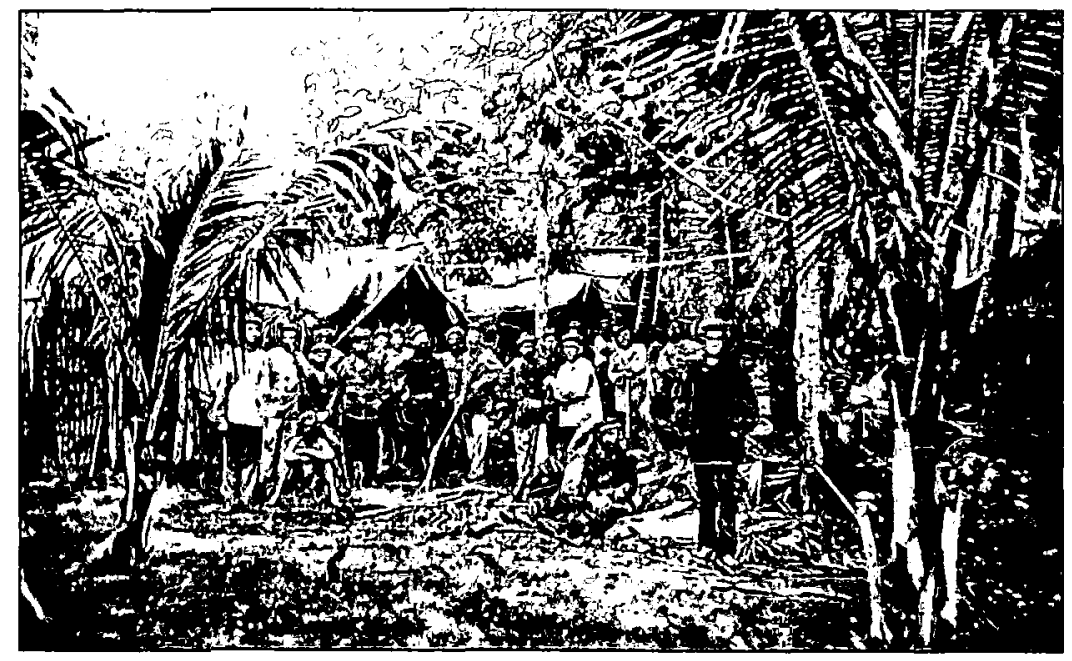

Figtre 3. Italian would-be Utopians at La Nouvelle-France, November 13, 1880: This shows a number of the Italians in typical European dress, with several in some sort of uniform, and armed, plus several naked natives. Behind are the canvas tents in which most people were still living.

Soure: Brown 1908 . 
implements; but it was evident that there had been great carelessness in shipping the material or in landing it, as they had cases of knife handles without any blades, and a number of wheelbarrows, but no wheels. They had scarcely any axes, and the few spades with which they were supplied appeared to be of the worst possible material. They had no quinine and few other medicines. ${ }^{52}$

Into the midst of the tragic collapse of this utopian scheme, fresh instructions from the Marquis de Rays arrived aboard the Nouvelle Bretagne, with "elaborate directions as to how to lay out the future city of this colony. ... to set aside a portion for the 'noblesse,' another portion for the 'bourgeois,' and another for the 'ouvriers.' . . to select a suitable site for the barracks for the 'gendarmes,' and definite instructions were given as to the size and locality of site on which the cathedral was to be erected." "33 One survivor recalled that their main building, "the blockhouse," with weatherboard walls, was "divided into sections ... about 14 to 16 feet wide $(4-5 \mathrm{~m})$ to the depth of the shed, in this lived a lot of people.... At one end was the part used for the church, then came the different families... . The priest made use of the church for a sleeping room." $\mathrm{He}$ also found that land "available for cultivation was very poor it consisted of a flat of no more than Ioo acres (40ha) if that much." ${ }^{\text {s4 }}$

In spite of the hardships,.Dr. Brown was impressed that the Italian peasants had started gardens and noted that the "women and children ... were certainly doing their full share of the hard work necessary in clearing the dense scrub." ${ }^{55}$ Meanwhile, these Italians were dying from tropical diseases, native attacks, and malnutrition. The promised support from France never materialized, as the Marquis de Rays's fraudulent scheme collapsed under gross mismanagement and heartless indifference, while their appointed, interim leader, Captain Rabardy, went insane, adding to their miseries. ${ }^{56}$

On February 20, I88I, the remaining settlers, including the Italians, abandoned La Nouvelle-France and traveled to Noumea, New Caledonia, on the India, their "disabled steamer ... having on board over 300 starving souls, with not a drop of water to drink. ... When water and food were taken on board a rush was made by the poor creatures. "' 57 After they arrived in Noumea on March I2, French officials seized and sold their decrepit ship. ${ }^{58}$

The Italians who reached Noumea were the lucky ones, even if they were stranded and destitute. A British official in the area reported that six Italian men who had earlier stolen away from La Nouvelle-France in a small boat reached 


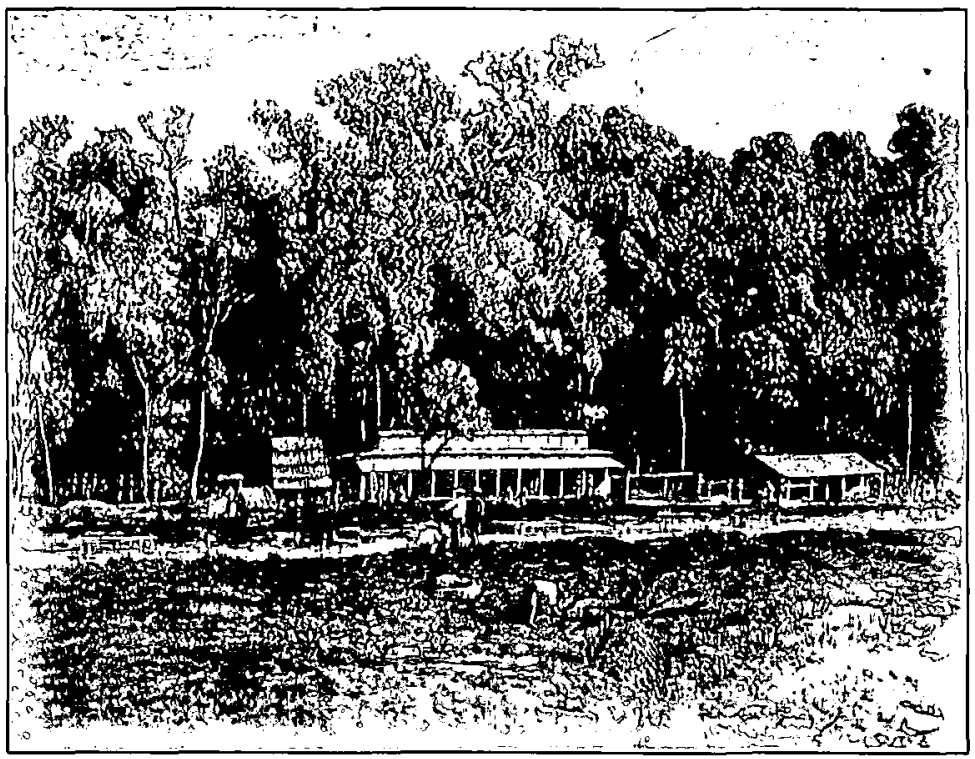

Figure 4. La Nouvelle-France 1881: This woodcut shows people working in gardens in the foreground, plus various huts and their stockade in the background, beyond the swampy area. Surre: Sydncy Mail, 16 April 1881, 621.

the Solomon Islands, where five were immediately killed and eaten. The sixth, Mr. Boero (or Buoro), was spared because he could entertain the locals by bursting into tears. He was sold to another tribe where he "became as big a cannibal as any of them." A year later, this man was sold to a labor-recruiting ship, but when the crew washed him and discovered that he was "an Italian who could not be sold into servitude, he was left at New Britain, as having no further commercial value," by this time having become "hopelessly imbecile." 59

The Missionaries of the Sacred Heart, whom the Marquis de Rays had recruited to serve his community, had been unable to join the four chartered vessels but nevertheless managed to get to La Nouvelle-France. When they arrived, the project had already collapsed, with most settlers either dead or having fled. They recorded: "The pitiful remains of the colony of Nouvelle-France: some graves on the sea shore, one large building called the blockhouse where most of the colonists had lived and which served as dormitory, infirmary, kitchen and guardhouse; a few makeshift houses built of straw and tree branches, some small and overgrown vegetable gardens. Huge trees had been felled but the flooding rains had washed away all attempts at cultivation."6o 


\section{The Fate of the Surviving Italian Peasants}

The fate of these destitute, would-be utopian communal settlers stranded in Noumea became something of a cause célèbre in Australia. Since all the Australian colonies were seeking migrants, the New South Wales colonial government quickly agreed to bring the Italians to Sydney, where, it was hoped, they would blend into the wider Australian society as laborers and small farmers. On April 7, I88I, about two hundred Italian survivors landed at Sydney. ${ }^{6 r}$ A reporter from the Sydney Morning Herald described the scene on board the James Patterson when it reached Sydney Harbour:

The more one sees on board the more one is struck with the horrors of the whole insane attempt that has been the cause of such misery. . . Several poor women-two of them young girls of eighteen to twenty-were stretched helpless, the victims of fever. One was a mother beside a child, lifted up to show that it was a living, or rather a dying skeleton. From another berth where another sick mother was also languishing, a small parcel was handed to me. From its size and shape ... I thought that it was an Italian doll made of wood and rags. A movement of its head made me start, and my heart beat quicker on finding that it was a living child of, I supposed, a few days old. ... I asked its age, when I was told it was seven months old. ...

From the most careful inquiries made of the emigrants themselves and those in charge of them, gross mismanagement and cruel deception, if not criminal desertion of the colonists, are the only conclusions to be arrived at. ${ }^{62}$

These Italian refugees requested a grant of land on which to collectively settle. The government, having a clear policy against allowing settlement within ethnic enclaves, refused, instead encouraging them to separate and accept employment as individuals. The Italians had "an almost insuperable objection to being dispersed among the general population," while the government had "an equally strong objection to making them a sort of colony within the colony ... [by] settling on the land in a body." ${ }^{{ }_{63}}$ The government's will prevailed, and the refugees were dispersed. ${ }^{64}$ 
A year later, however, a number of these Italians started acquiring land near the Richmond River, abour seven hundred kilometers (five hundred miles) north of Sydney, and there established a semicommunal settlement known first as "La Cèa Venèssia" and later as "New Italy."65 They set up communal social structures to manage their community, even though the land was privately owned. Speaking Italian, they declined to take part in local politics and, at first, had little to do with their non-Italian neighbors.

A contemporary observer described New Italy as a "prosperous little settlement" with "happy and contented" members and opined that they should be thankful that they had escaped "a spurious Utopia to dwell in a country where the conditions of climate are like those of their own sunny Italy." He wondered, however, if "they think sometimes of those of their former comrades who died . . . in the savage 'colony' of Charles du Breil."

The full story of New Italy is too long to be included here, but this intentional community grew to have over two hundred members by the start of the twentieth century, after which it slowly shrank as members, particularly the second generation, moved away from the constrictions of ethnically based communal life and embraced individualism. The New Italy School closed in 1933, and the last resident died in $1955 .{ }^{67}$

\section{The Fate of the Marquis de Rays}

Hugh Romilly, a British official sent to New Ireland to investigate this utopian fraud, summed up his report by saying, "Altogether a more disgraceful scheme was never planned," and this led several countries to seek to punish the perpetrator. ${ }^{68}$ On July 15, I882, the Marquis de Rays was arrested in Spain, to which he had fled, and transported to France, where he was tried for embezzlement: "The court sat breathless as the pitiful story was unfolded and eyes filled with tears [at] accounts of the disease and distress that had thinned the ranks of the little colony." In January 1884 , he was fined and sentenced to four years in prison (on top of the eighteen months he had already been incarcerated). As well, several of his underlings were sentenced to prison. ${ }^{69}$

Once out of prison in 1888 , the Marquis de Rays operated briefly as a gigolo, specializing in preying on rich American women, and tried several more fraudulent schemes such as selling finely ground granite as gunpowder, prior to his death on July 29, $1893 .^{70}$ The well-known American writer James Michener 
described the Marquis de Rays: "Of all the criminals who have pillaged the South Pacific, the most brutal and callous was a gentleman who never reached that region. Cynically, he defrauded thousands of their money, sent hundreds to certain death, and lived in luxury on the proceeds of his villainy."

The Marquis de Rays's closest accomplice and his highly effective propagandist, Dr. Paul de Groote, somehow avoided prison but lost his own money and health. It is likely that de Groote negotiated his own freedom by turning "statẹ's witness" and testifying against de Rays, but the trial records cannot be found. In I884, after de Rays was imprisoned, de Groote, with his wife, Leontine, and their six children, fled Europe and settled in Los Angeles. In America, they hoped not only to escape the law but also to rebuild their fortunes lost through this scheme. Several years later, the family returned to Belgium, where de Groote died in $1890^{72}$ One survivor described de Groote as being "equally dishonest" as de Rays and claimed that de Groote's writings were "a wicked, insidious lie, cleverly worded in order to ensnare the credulity of his prey." 33 There is no evidence that Dr. Paul de Groote ever regretted his crucial role in this scheme that led to the deaths of many naive, would-be utopian settlers.

\section{Summary and Conclusion}

The wonder is not that La Nouvelle-France collapsed as a utopian communal venture but, rather, that it managed to be established in New Ireland. While many died there, about two hundred others escaped to Australia to establish another semi-utopian community that has long since collapsed. Today, beside the busy Pacific Highway between Sydney and Brisbane, a cairn attests, in Italian and English, to this failed utopian social experiment, while a small museum houses a few artifacts plus an Italian café serving tourists.

Notes

I. I have discussed this assertion with other utopian scholars such as Professors Lyman Tower Sargent and Toby Widdicombe without them suggesting a bigger fraudulent scheme, so my assertion stands until contrary evidence arises.

2. Most of the demographic information has been gleaned from secondary sources, and although most are poorly referenced they appear to be consistent and so have been tentatively accepted. Primary source verification has been followed whenever possible. 
3. Bogershausen n.d. (ca. 1900), I; and Niau 1936, $1-4$.

4. Paul de Groote was born March 27, 1836, and became a medical doctor in Brussels. He somehow connected with the Marquis de Rays, through whom he became "Consul Gencral of New France," and, after June 1879 , ediced La Nouvelle-France newspaper, the main propaganda arm of this utopian scheme. In $\mathrm{r} 880$, de Groote published a sycophantic book called Nouvelle-France, Colonic Libre de Port-Breton (based on information provided to me by members of the de Groote family, Belgium; see also Biskup 1974, 12-13).

5. De Groote 1880, 14: "Son extérieur, reflet du sentiment de sa force, de son courage calme, de sa bonté exquisc, impose le respect et la confiance. Le Marquis de Rays est assurément né pour le commandement; il en a l'assurance, la spontanéité, la résolution, la précision du coup d'ouil; il possède à la fois à un haut degré les vertus chrétiennes, l'instinct militaire, le génie du marin, la prévoyance de l'administrateur, er l'impartialité éclairée du jurisconsulte." The original French text is provided here for the first quote from this very important book, as well as the translation by Estelle Gaillard, my Ph.D. student, and me. To save space, only the English translation is provided henceforth.

6. Ibid., i6. A later scholar, McMahon, has described de Groote's book as "a masterpiece of rhetoric and imagination" (1982, 12). There is no evidence that the Marquis de Rays ever came anywhere near Australia.

7. The concept of a South Pacific utopia has had a long history in Western Europe. See, for example, Fausett 1993; Friedrich 1967; and Gibson 1984.

8. Du Breil 1879 .

9. Collingridge 1923,14 .

10. Sydney Daily Telegraph, 18 March 1880,2 ; and Collingridge 1923, I4.

II. Collingridge 1923, 14.

12. Du Breil 1879,19 ; and Clifford 1889,4 .

13. Du Breil 1879, 13, 20.

14. De Groote $1880,35$.

I5. Ibid., 86, 5 I.

16. Ibid., 102. See also du Breil 1879, เ3.

17. De Groote 1880; 12I.

I8. Romilly $1886,197$.

19. Beck 1899, 237.

20. De Groote 1880,122 .

21. Three years later, in 1884 , New Ireland was seized by the German navy, and it became part of Germany's colony of Kaiser-Wilhelmsland, otherwise known as German New Guinea. Today it is part of Papua New Guinea.

22. Romilly 1886,39 .

23. Ibid., 38-62.

24. Beck 1899, 235.

25. De Groote 1880 , 125. See also du Breil I879, 14-15.

26. De Groote 1880,82 .

27. Du Breil r879, i4.

28. De Groote 1880,76 . 
29. Du Breil $1879,7-8$.

30. De Groote 1880,166 .

31. Ibid., 150.

32. Ibid., I24.

33. Du Breil 1879, 15.

34. Biskup 1974, 13 .

35. Ibid., 79-80.

36. Du Breil 1879,9 , Ir. Offices were established in Paris at 5 rue de la Ville-J'Evêque and in Marseille at in rue de la République. The application forms to be used to subscribe to this uropia can be found in ibid., $21-22$.

37. Ibid., 9-11; de Groote 1880, 123-50; Clifford 1889, I; and Sydney Morning Herald, 9 April $1881,3$.

38. See, for example, Fausett 1993, 1994; Lansdown 2006; Longley 1999; Rennie I995; Smith 1984 ; and Spate 1988.

39. Spate $1988,69,82$.

40. Bernardi 1994, 33-79; Thompson 1980, 3; and Pryor 1986, I-9.

41. McMahon 1982, 12. See also Dupeyrat 1934.

42. Niau 1936, 20-21.

43. Sceusa $188 \mathrm{I}, 9-2 \mathrm{I}$.

44. Brown 1908, 359.

45. Sydney Morning Herald, 18 March $1880,5,7$.

46. Tudor 1949, 43.

47. Brown 1908, 359.

48. Nicholson 1993, I71.

49. Sceusa I88I, 21.

50. Piccoli $1944,6$.

5I. Brown 1908, 358-67.

52. Ibid., 363-64. A photograph between pages 354 and 355 shows the discarded steam boiler. A millstone, about 1.5 meters across, still can be seen in a park in the nearby city of Rabaul.

53. Sceusa 1881, 51-53; and Brown 1908, 362. Ouvrier refers to a workman.

54. Biskup I974, 50-5I.

55. Brown $1908,367-68$.

56. Sceusa 1881, 24-28.

57. Sydney Morning Herald, 24 March $188 \mathrm{i}, 6$.

58. Sceusa 1881, 28; Sydney Morning Herald, 24 March I881, 6; and Sydney Mail, 26 March 188I, 50I.

59. Romilly 1886, 14-15; Pryor 1986, 30; and Biskup 1974, 62.

60. McMahon 1982, I6.

6I. Sydney Morning Herald, 8 April I88I, 3-5, and 9 April I88I, 3; Sydney Daily Telegraph, 9 April 188I, 7, and II April.188I, 3; and Marsh and Wise I88I.

62. Sydney Morning Herald, 9 April $1881,3$.

63. Ibid., 22 April 188I, 5. 
64. Sceusa I88I, 39-4I.

65. Cèa is dialect for small, while Venèssia is dialect for the region around Treviso, north of Venice. The phrase "La Cèa Venèssia" is the dialect name for the region from where these people had come.

66. Beck $1899,243$.

67. Harrigan 2006; Thompson I980; and Volpato 1983 ;

68. Romilly 1886 , 199.

69. Vermont 1884; and Biskup 1974, 52, 55.

70. Niau 1936, 186-89.

71. Michener 1957, 51 .

72. Information derived from the records of Celine de Groote, sister of Dr. Paul de Groote, and contained in an e-mail (Pebruary 22, 2008) to the author from Philippe de Groote, Prance, a direct descendant of Dr. Paul de Groote.

73. Piccoli 1944, 5.

\section{Works Cited}

Beck, Louis. Ridan the Devil and Other Stories. London: T. Fisher Unwin, 1899.

Bernardi, Ulderico. A Catdr Fortuna. Treviso: Giunta Regionale del Veneto, 1994.

Biskup, Peter, ed. The New Guinea Memoirs of Jean Baptiste Octave Mouton. Canberra:

Australian National University Press, 1974.

Bogershausen, Georg. Das Paradies der Suedsee.. Monograph held by the Fryer Library, Brisbane, n.d. (ca. 1900).

Brown, George. George Brown, D. D. Pioneer-Missionary and Explorer: An Autobiography. London: Hodder and Stouton, 1908.

Clifford, Charles. New Italy: A Brief Sketch of a New and Thriving Community. Sydney: Charles Potter, Government Printer, 1889.

Collingridge, George. "Colonization by Prospectus." Forum: A Joumal for Thinking Australians 1, no. 24 (April 11, 1923): 14.

de Groote, Paul. Nouvelle-France, Colonie Libre de Port-Breton. Paris: Société Générale de Libraire Catholique, $\mathbf{1 8 8 0 .}$

du Breil, Charles. La Colonie Libre de Port-Breton. Marseille: Typographie et Lithographie Marius Olive, 1879.

Dupeyrat, Andre. Papouasie. Paris: Dillen, 1934.

Fausett, David. Images of the Antipodes in the Eighteenth Century. Amsterdam: Rodopi, 1994. Writing the New World. Syracuse: Syracuse University Press, 1993.

Friedrich, Werner. Australia in Western Imaginative Prose Writings 1600-1960. Chapel Hill: University of North Carolina Press, 1967.

Gibson, Ross. The Diminishing Paradise. Sydney: Angus and Robertson, 1984.

Harrigan, Rosemary. They Were Expeditioners. Werribee, Australia: Rosemary Harrigan, 2006. Lansdown, Richard. Strangers in the South Seas. Honolulu: University of Hawaii Press, 2006. 
Longley, Paul. "Fantasies of the Antipodes." In Imagining Australian Space: Cultural Studies and Spatial Inquiry, ed. R. Barcan and 1.Buchanan, 37-46. Nedlands: University of Western Australia Press, 1999.

Marsh, James, George Wise. Italian Immigrants Inquiry Board. Sydney: Government Printer, $188 \mathrm{I}$.

McMahon, John. "The Marquis and the Missionaries." Annals Australia: Journal of Catholic Culture, October 1982: 10-16.

Michener, James. Rascals in Paradise. London: Secker and Warburg, 1957.

Niau, Josephine. The Phantom Paradise: Sydney: Angus and Robertson, 1936.

Nicholson, Ian. Log of Logs. Nambour, Australia: Sunstrip Printers, 1993.

Piccoli, Giacomo. Chronicle of New Italy's Early Settlement. Monograph dictated to P. Malone and now held by the Richmond River Historical Society. Woodburn, Australia, 1944.

Pryor, Philip. "New Italy —A Refuge from Misadventure." M.A. thesis, University of Sydney, 1986.

Rennie, Neil. Far-Fetched Facts: The Literature of Travel and the Idea of the South Seas. Oxford: Oxford University Press, 1995.

Romilly, Hugh. Western Pacific and New Guinea. London: John Murray, 1886.

Sceusa, Francis. La Spedizione del Marchese di Rays e le Sue Vittime. Sydney: H. R. Woods and Co., 188I.

Smith, Bernard. European Vision and the South Pacific. Sydney: Harper and Row, 1984.

Spate, Oskar. Paradise Found and Lost. London: Routledge, 1988.

Thompson, Anne-Gabrielle. Turmoil-Tragedy to Triumph. Stanthorpe, Australia: International Colour Productions, 1980 .

Tudor, Judy. "The Marquis Provided the Mill-Stone." Pacific Islands Monthly 19, no. 7 (1949): 43, 57.

Vermont, Marie. Le Procès du Marquis de Rays. Marseille: V. Groupy et Jourda, 1884. Volpato, Floriano. New Italy: Il Globo-La Fiamma. Lismore, Australia: Floriano Volpato, 1983. 


\title{
COPYRIGHT INFORMATION
}

\author{
Author: Metcalf, Bill
}

Title: Utopian Fraud: The Marquis de Rays and La Nouvelle-France

Source: Utopian Stud 22 no1 2011 p. 104-24

ISSN: $1045-991 \mathrm{X}$

Publisher: Society of Utopian Studies

Pennsylvania State University Press, 820 N. University Drive, University Support Bldg. 1, Suite C, University Park, PA 16802

The magazine publisher is the copyright holder of this article and it is reproduced with permission. Further reproduction of this article in violation of the copyright is prohibited.

\footnotetext{
This article may be used for research, teaching and private study purposes. Any substantial or systematic reproduction, re-distribution, re-selling, loan or sublicensing, systematic supply or distribution in any form to anyone is expressly forbidden. The publisher does not give any warranty express or implied or make any representation that the contents will be complete or accurate or up to date. The accuracy of any instructions, formulae and drug doses should be independently verified with primary sources. The publisher shall not be liable for any loss, actions, claims, proceedings, demand or costs or damages whatsoever or howsoever caused arising directly or indirectly in connection with or arising out of the use of this material.
} 